\title{
Pemanfaatan serat alam kulit terap sebagai bahan kombinasi pembuatan winglet sepeda motor
}

\author{
Ari Rianto', Leo Dedy Anjiu², Suhendra ${ }^{3 *}$ \\ Jurusan Teknik Mesin, Politeknik Negeri Sambas ${ }^{1,2,3}$ \\ Jl. Raya Sejangkung, Sambas \\ *Corresponding author: aka.suhendra@yahoo.com
}

\begin{abstract}
The development of new natural fiber material as a composite reinforcing material needs to be continued. The use of natural fibers developed in this study was obtained from applied bark. The applied skin fiber is chosen as a composite reinforcing material because it has strong characteristics when pulled. This study was conducted to determine the impact strength of a combination of the arrangement of the composite layer of applied fiber and glass fiber with a polyester resin matrix in the manufacture of motorcycle winglets. The making of composite specimens was carried out by hand lay-up and pressing techniques. composite specimens tested consisted of composite A (100\% fiberglass), composite B (100\% applied fiber), composite $C$ (fiberglass, applied fiber, fiberglass), and composite $D$ (applied fiber, fiberglass, applied fiber). The treatment of the applied fiber was carried out by soaking 5\% $\mathrm{NaOH}$ for 2 hours. Impact test specimens and procedures refer to the ASTM D256-00 standard. The results of the study obtained that the material recommended in the manufacture of motorcycle winglets is composite $C$, which is a combination of fiberglass, applied fiber, fiberglass. The results of the C composite impact strength testing were obtained at $2.6581 \mathrm{~J} /$ mm2. The impact strength of composite $C$ increased by $79 \%$ compared to the impact strength of composite B using pure applied fiber (100\% applied fiber). The large void tendency in natural fiber composites using the hand lay-up method reduces the impact strength so that fiberglass is more dominant as a determinant of the impact strength increase.
\end{abstract}

Keywords : Applied fiber, impact test, winglet.

\begin{abstract}
Abstrak
Pengembangan material baru serat alam sebagai bahan penguat komposit perlu terus dilakukan. Penggunaan serat alam yang dikembangkan dalam penelitian ini diperoleh dari bahan kulit kayu terap. Serat kulit terap dipilih karena memiliki karakteristik yang kuat saat ditarik. Penelitian dilakukan untuk mengetahui kekuatan impak dari kombinasi susunan lapisan komposit serat terap dan fiber glass dengan matrik resin poliester pada pembuatan winglet sepeda motor. Pembuatan spesimen komposit dilakukan dengan teknik hand lay-up dan pressing. Spesimen komposit yang diuji terdiri dari : komposit A (100\% fiberglass), komposit B (100\% serat terap), komposit C (fiberglass, serat terap, fiberglass) dan komposit D (serat terap, fiberglass, serat terap). Perlakuan serat terap dilakukan dengan perendaman $5 \% \mathrm{NaOH}$ selama 2 jam. Spesimen dan prosedur pengujian impak mengacu pada standar ASTM D25600. Hasil penelitian memperoleh bahan yang dianjurkan dalam pembuatan winglet sepeda motor adalah komposit $\mathrm{C}$ yaitu kombinasi lapisan fiberglass, serat terap, fiberglass. Hasil pengujian kekuatan impak komposit $\mathrm{C}$ diperoleh sebesar 2,6581 J/mm². Kekuatan impak komposit $\mathrm{C}$ naik sebesar 79\% dibandingkan dengan kekuatan impak komposit B menggunakan serat terap murni (100\% serat terap). Kecendrungan void yang besar pada komposit serat alam menggunakan metode hand lay up menurunkan hasil kekuatan impak sehingga fiberglass lebih dominan menjadi penentu kenaikan kekuatan impak.
\end{abstract}

Kata kunci : Serat terap, uji impak, winglet. 


\section{Pendahuluan}

Kayu terap (Arthocarpus elasticus) merupakan salah satu potensi alam Indonesia yang tumbuh subur di pulau Kalimantan khususnya Propinsi Kalimantan Barat. Pemanfaatan kulit kayu terap oleh masyarakat Kalimantan Barat biasa digunakan sebagai tali, kerajinan dan bahan pakaian oleh suku Dayak. Kekuatan yang baik dalam arah lateral dan struktur anyam yang alami adalah salah satu kelebihan serat ini sehingga dapat dikembangkan sebagai alternatif material baru bahan penguat komposit. Pemanfaatan serat kulit kayu terap sebagai bahan penguat komposit perlu dikembangkan karena karakteristiknya yang kuat saat ditarik sehingga layak dianalisis lebih lanjut.

Perlakuan terhadap serat alam perlu dilakukan untuk menghilangkan kandungan lignin yang terdapat pada serat alam. Kandungan lignin yang terkandung dalam serat alam menyebabkan ikatan antara serat dan matrik tidak menyatu dengan baik sehingga distribusi gaya dari matrik ke serat alam lemah. Modifikasi permukaan dapat dilakukan untuk meningkatkan sifat adhesif antara serat alam dengan matrik.

Beberapa penelitian tentang kekuatan mekanik komposit dengan berbagai jenis serat alam telah dilakukan. Kekuatan mekanik komposit serat alam dengan matrik resin epoxy, menggunakan serat enceng gondok (eichornia crassipes), serat daun pandan alas (pandanus dubius), dan serat batang pisang raja (musa textilia) menunjukkan bahwa serat enceng gondok memiliki kekuatan tarik terbesar dibandingkan serat lainnya pada komposisi serat $40 \%$, yaitu $18,14 \mathrm{kgf} / \mathrm{mm}^{2}$. Serat daun pandan alas memiliki regangan terbesar dibandingkan serat lainnya pada komposisi serat $40 \%$, yaitu sebesar 5\%, sedangkan modulus young terbesar diperoleh pada serat enceng gondok pada komposisi serat $50 \%$, yaitu 551,44 kgf $/ \mathrm{mm}^{2}$ [1].

Penelitian lainnya menggunakan serat rami dengan variasi lama perendaman
0, 2, 4, dan 6 jam, menunjukkan bahwa kekuatan dan regangan tarik komposit memiliki harga optimum untuk perlakuan serat 2 jam, yaitu 190,27 MPa dan 0,44\%. Komposit yang diperkuat serat dengan perlakuan 6 jam memiliki kekuatan terendah. Penampang patahan komposit yang diperkuat serat pada perlakuan 0,2 , dan 4 jam diklasifikasikan sebagai jenis patah slitting in multiple area. Sebaliknya, penampang patahan komposit yang diperkuat serat pada perlakuan 6 jam memiliki jenis patah tunggal [2].

Penelitian menggunakan serat terap sebagai bahan penguat komposit telah dilakukan. Hasil penelitian [3] mendapatkan kekuatan impak tertinggi diperoleh pada variasi berat serat 4 gram dan panjang serat $5 \mathrm{~mm}$ sebesar 0,591 $\mathrm{J} / \mathrm{mm}^{2}$. Kekuatan impak cenderung meningkat seiring bertambahnya berat serat dan mencapai puncaknya pada berat serat 4 gram.

Berdasarkan latar belakang tersebut, perlu dilakukan penelitian lanjutan dengan menggabungkan serat alami dan serat sintetis. Serat alami yang digunakan adalah serat terap, sedangkan serat sintetis yang digunakan adalah fiberglass yang tersusun secara acak (reinforcing mat). Pengembangan material tersebut digunakan sebagai bahan pembuatan winglet pada sepeda motor.

\section{Tinjauan Pustaka}

Berdasarkan jenisnya, serat dibagi menjadi serat alam (nature fiber) dan serat sintetis (buatan). Serat sintetis merupakan serat yang dibuat untuk menghasilkan bahan dengan sifat tertentu, namun serat sintetis memiliki beberapa kelemahan. Kelemahan serat sintetis terdapat pada sifat biodegradibilitas, pengolahan awal memerlukan biaya tinggi, konsumsi energi yang besar, abrasi mesin serta dampak terhadap kesehatan manusia dan lingkungan sekitar [4]. Kelemahan serat sintetis yang banyak merugikan perlu diatasi dengan mengganti jenis serat sintetis ke serat alam. 
Serat alam adalah serat yang dibentuk dari bahan dasar tumbuhan atau hewan. Serat alam dapat dibentuk dari berbagai jenis tumbuhan seperti kapas, pelepah pisang, enceng gondong dan rami [5]. Jenis serat alam yang diperoleh dari hewan adalah wool, sutra dan bulu burung.

Material komposit dibentuk dari kombinasi dua atau lebih bahan untuk mendapatkan sifat yang lebih baik dari sifat bahan penyusunnya [6]. Keunggulan penggunaan bahan komposit antara lain memiliki bobot ringan, relatif tahan terhadap bahan kimia dan tahan korosi.

Sifat dan karakteristik komposit ditentukan oleh beberapa faktor antara lain oleh [7] :

1. Jenis material penyusun dan rule of mixture.

2. Bentuk dan struktur penyusun komposit

3. Interaksi antar penyususn komposit. Sifat mekanik bahan komposit alam dapat dilihat dari beberapa parameter seperti kekuatan serat, modulus young, ikatan antar permukaan serat, matrik penyusun serat dan panjang serat. Salah satu metode uji untuk mengetahui sifat mekanik bahan komposit adalah uji impak.

Pengujian impak (kejut) bertujuan untuk mengukur besarnya energi yang dapat diserap oleh suatu bahan komposit sampai bahan tersebut patah dengan jenis beban yang diberikan adalah beban tibatiba. Pengujian impak terdiri dari dua teknik pengujian standar yaitu charpy dan Izod.

Pengujian impak dilakukan berdasarkan standar ASTM D256-00. Spesimen charpy berbentuk batang dengan penampang melintang berbentuk bujur sangkar dengan takikan "v". Pembuatan takikan dilakukan oleh proses permesinan (Gambar 1.a). Nilai pembebanan uji impak diperoleh dari tumbukan palu pendulum yang dilepas pada ketinggian "h". Ujung pisau pada palu pendulum akan menabrak takikan pada spesimen hingga patah. Takikan pada spesimen merupakan titik konsentrasi tegangan untuk pukulan impak kecepatan tinggi. Palu pendulum akan meneruskan ayunan hingga mencapai ketinggian maksimum tertentu h'. Energi yang diserap dihitung dari perbedaan $h$ ' dan h (mgh - mgh'), merupakan ukuran dari energi impak. Posisi simpangan lengan pendulum terhadap garis vertikal sebelum dibenturkan adalah $\alpha$ dan posisi lengan pendulum terhadap garis vertikal setelah membentur spesimen adalah $\beta$. Besarnya energi potensial yang diserap oleh material digunakan untuk menghitung kekuatan impak benda uji [9].

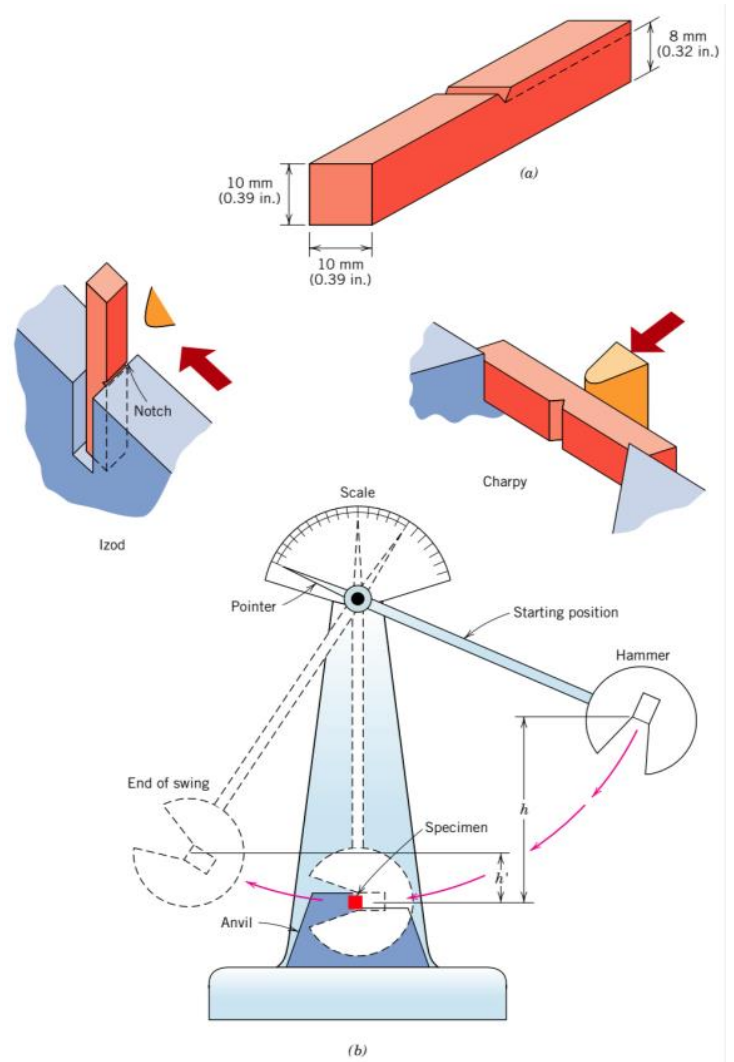

Gambar 1. (a) Spesimen pengujian impak. (b) Skematik peralatan uji impak [8]

\section{Metode Penelitian}

Pengujian impak spesimen komposit dilakukan di laboratorium pengujian bahan Jurusan Teknik Mesin Politeknik Negeri Sambas.

Bahan yang digunakan adalah serat kulit terap, resin poliester, katalis, talk, $\mathrm{NaOH}$, dempul, mirror glass, pigmen, aerosil. Peralatan yang digunakan yaitu alat cetak, timbangan digital, gelas ukur, kuas, gerinda, amplas, siku, gelas plastik, jangka sorong, gunting, catter. 


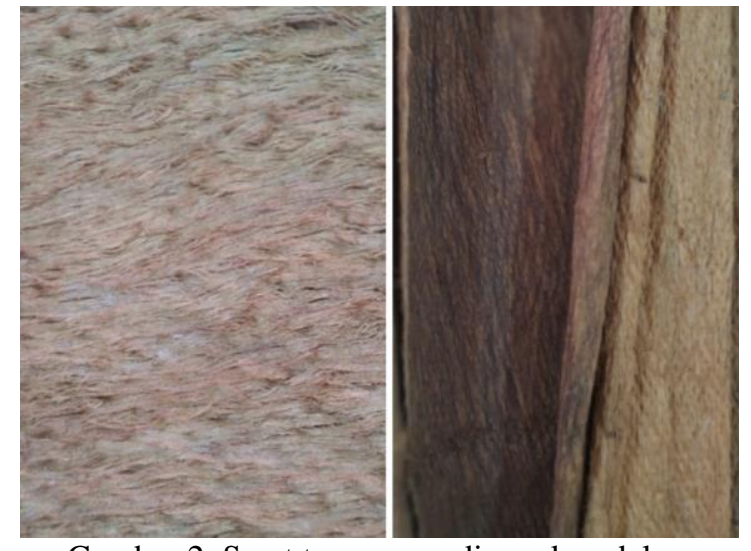

Gambar 2. Serat terap yang digunakan dalam pembuatan spesimen

Tahap awal penelitian adalah mempersiapkan serat terap. Proses persiapan dilakukan dengan merendam serat terap pada $\mathrm{NaOH}$ yang telah dilarutkan. Kadar $\mathrm{NaOH}$ yang dilarutkan sebesar 5\% dari massa air yang digunakan. Rendam serat terap yang telah tercampur merata dengan $\mathrm{NaOH}$ selama 2 jam. Angkat serat terap yang telah direndam, selanjutnya cuci dengan air bersih untuk menghilangkan kandungan $\mathrm{NaOH}$. Lakukan proses pemukulan pada serat terap hingga serat memanjang dan merenggang, kemudian jemur hingga kering. Serat terap yang telah dikeringkan selanjutnya dipotong dengan ukuran sesuai luas cetakan yang sudah ditentukan. Suwir serat terap, agar penampang serat menjadi lebih kecil sehingga resin mudah mengikat serat. Susun serat yang sudah disuwir menjadi susunan acak selebar ukuran cetakan. Persiapan terhadap fiberglass dilakukan dengan mengukur dan memotong fiberglass reinforcing mat sesuai ukuran cetakan yang telah ditentukan.

Tahapan kedua adalah proses pembuatan spesimen uji. Persiapkan cetakan spesimen dengan ukuran panjang $10 \mathrm{~cm}$, lebar $7 \mathrm{~cm}$ dan tinggi $1 \mathrm{~cm}$. Oleskan mirror glaze pada permukaan cetakan untuk mempermudah proses pelepasan spesimen. Persiapkan resin yang sudah dicampur katalis, serat terap dan fiberglass reinforcing mat.

Pembuatan spesimen uji sesuai dengan perbandingan bahan sebagai berikut
1. Spesimen A: 103 gram resin $+1 \%$ katalis + 9 lembar mat.

2. Spesimen B: 103 gram resin $+1 \%$ katalis + serat terap.

3. Spesimen C: 103 gram resin $+1 \%$ katalis dan menggunakan kombinasi fiberglass, serat terap, fiberglass.

4. Spesimen D: 103 gram resin $+1 \%$ katalis dan menggunakan kombinasi serat terap, fiberglass, serat terap.

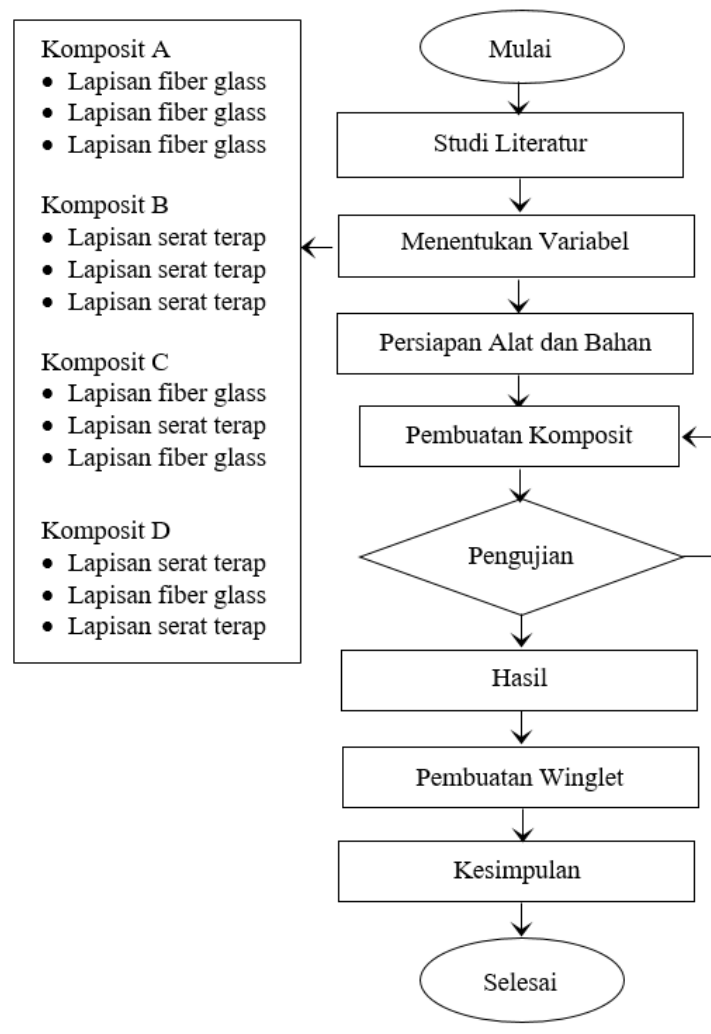

Gambar 3. Diagram alir penelitian

Potong spesimen berukuran $15 \mathrm{~mm}$ sesuai dengan standar pengujian yang telah ditetapkan pada ASTM D256-00. Mesin yang digunakan dalam pengujian adalah Universal Impact Tester Machine tipe HT8041. Takikan impak (notch) dibuat sesuai standar pengujian yaitu dengan kedalaman $2 \mathrm{~mm}$ dan sudut $45^{\circ}$. 


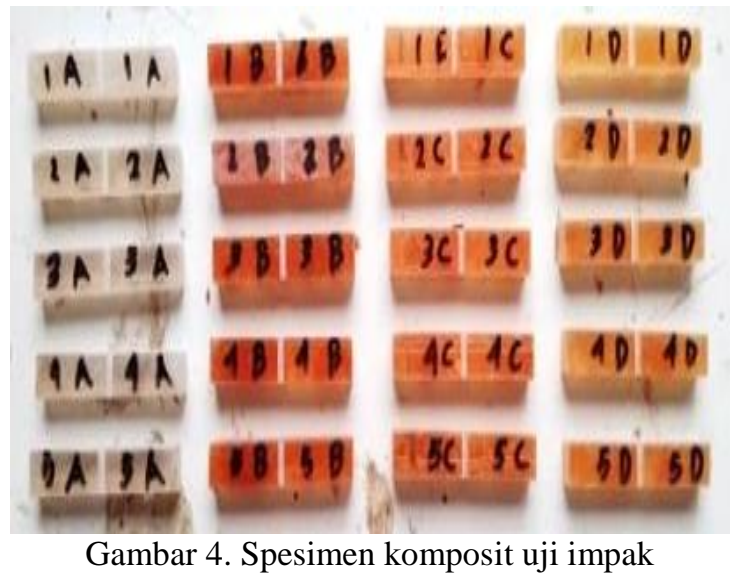

\section{Hasil dan Pembahasan}

1. Hasil pengujian impak charpy

Data hasil pengujian impak charpy menggunakan Universal Impact Tester Machine tipe HT-8041 dapat dilihat pada Gambar 5.

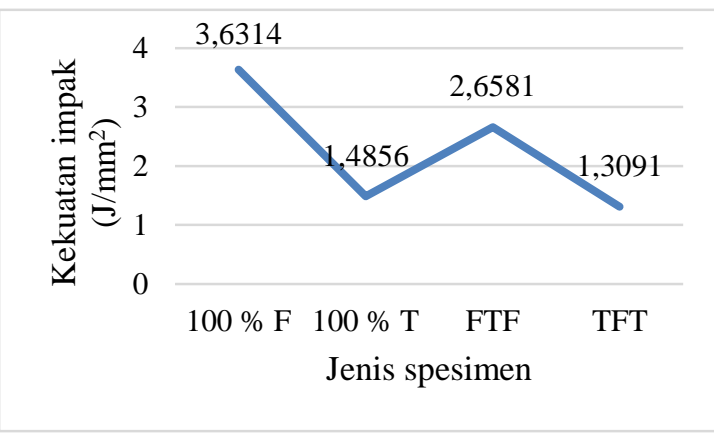

$100 \% \mathrm{~F}=100 \%$ fiberlass

$100 \% \mathrm{~T}=100 \%$ serat terap

$\mathrm{FTF}=$ Kombinasi fiberglass, serat terap, fiberglass TFT $=$ Kombinasi serat terap, fiberglass, serat terap

Gambar 5. Hasil pengujian impak charpy

Penggunaan $100 \%$ fiberglass menghasilkan kekuatan impak charpy pada spesimen uji sebesar $3,6314 \mathrm{~J} / \mathrm{mm}^{2}$. Penggunaan bahan $100 \%$ fiberglass menghasilkan kekuatan impak cukup besar. Penelitian lain menyatakan fiberglass lebih mudah menyerap resin, menghilangkan cacat dan ketidak sempurnaan kristal yang biasa terdapat pada bahan berbentuk padatan besar, sehingga dapat menghasilkan kekuatan yang besar [10].

Penggunaan $100 \%$ serat terap pada spesimen uji menurunkan $60 \%$ kekuatan impak charpy yaitu sebesar $1,4856 \mathrm{~J} / \mathrm{mm}^{2}$ dibanding menggunakan $100 \%$ fiberglass. Hal ini disebabkan perlakuan alkali yang berlebihan pada kosentrasi dan lamanya perendaman serat alam dapat menurunkan kekuatan tarik serat karena terjadi proses delignifikasi dan penetrasi pada rantai selulosa yang berlebihan sehingga menyebabkan kelemahan dan kerusakan serat [11]. Matriks termoseting seperti epoxy dan poliester kurang cocok jika dibuat sebagai komposit berpenguat serat alam. Perlakuan yang tepat perlu dilakukan pada pembuatan serat menggunakan $\mathrm{NaOH}$ sehingga dapat meningkatkan gaya tarik menarik antar molekul tidak sejenis antara matrik dengan serat alam tersebut [12].

Penggunaan kombinasi lapisan pertama fiberglass, lapisan kedua serat terap dan lapisan ketiga fiberglass (Spesimen C), menghasilkan kenaikan 79\% kekuatan impak charpy sebesar 2.6581 $\mathrm{J} / \mathrm{mm}^{2}$ dibanding menggunakan $100 \%$ serat terap. Peningkatan ini sejalan dengan kompaknya fiber dan resin dalam menerima beban Impak sehingga gaya terdistribusi dengan baik pada ikatan serat fiberglass dan resin sebagai matrik komposit.

Penggunaan kombinasi lapisan pertama serat terap, lapisan kedua fiberglass dan lapisan ketiga serat terap (Spesimen D) terjadi penurunan kekuatan impak sebesar 50\% dengan nilai 1.3091 $\mathrm{J} / \mathrm{mm}^{2}$. Penggunaan kombinasi tersebut kurang baik karena serat terap lapisan pertama dan lapisan ketiga memiliki kekuatan impak yang rendah yang akhirnya menurunkan kekuatan Impak karena beban yang diterima cepat menyebabkan crack pada beban yang kecil.

\section{Model Patahan}

Model patahan spesimen yang terbuat dari $100 \%$ fiberglass pada pengujian impak adalah jenis patahan ulet atau dikenal dengan patahan sikat (brush fracture). Kondisi ini dapat terjadi karena belum terserapnya fiberglass dan resin dengan sempurna sehingga terjadi debounding dan delaminating pada komposit yang mengakibatkan kekuatan impak kurang maksimal. Patahan yang baik pada komposit fiberglass seharusnya patahan getas karena sifat kompak antara 
matrik yaitu resin dan fiberglass cukup baik.

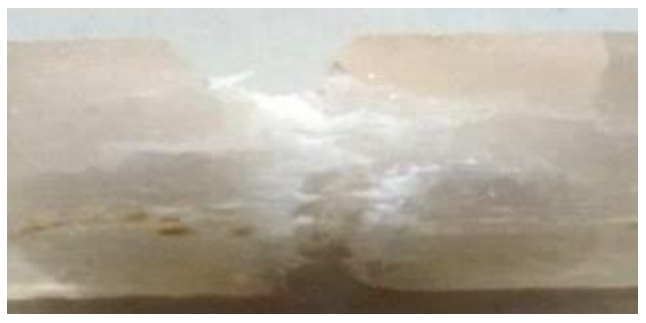

Gambar 6. Patahan spesimen $100 \%$ fiberglass

Spesimen B yang terbuat dari $100 \%$ serat terap pada pengujian impak adalah jenis patahan getas (brittle fracture). Patahan jenis ini sebenarnya jenis patahan yang diharapkan pada komposit dengan matrik resin poliester karena membuktikan tidak terjadinya debounding dan delaminating, akan tetapi kekuatan impak yang dihasilkan belum mampu mengalahkan kekuatan impak dengan $100 \%$ fiberglass.

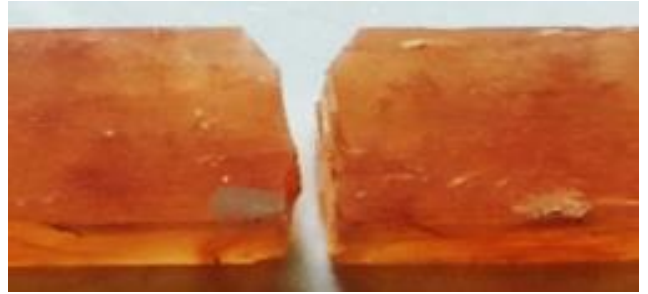

Gambar 7. Patahan spesimen $100 \%$ serat terap

Keadaan ini diperkirakan terjadi karena perlakuan serat dengan $5 \% \mathrm{NaOH}$ membuat serat lebih rapuh walaupun serat yang dihasilkan memiliki permukaan yang lebih bersih dari lignin, hemiselulosa dan pengotor lainnya [13].

Model patahan kombinasi fiberglass, serat terap, fiberglass (Spesimen C) dan patahan kombinasi serat terap, fiberglass, serat terap (Spesimen D) pada pengujian menghasilkan jenis patahan getas (brittle fracture) dan patahan sikat (brush fracture). Ciri-ciri patahan hasil pengujian mendapati bahwa terdapat butir-butir halus pada permukaan patahan spesimen, permukaan patahan spesimen uji mengkilap dan terdapat serabut-serabut kasar pada permukaan patahan berbentuk seperti sikat.

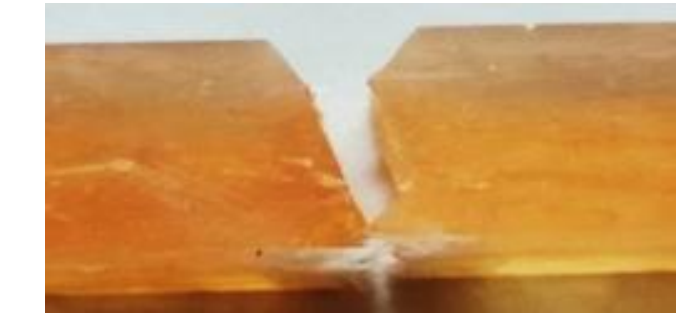

Gambar 8. Patahan spesimen kombinasi fiberglass, serat terap, fiberglass

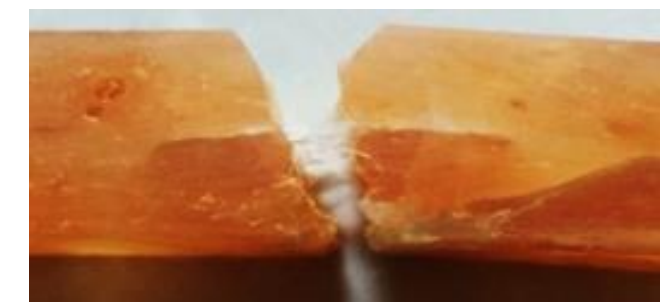

Gambar 9. Patahan spesimen kombinasi serat terap, fiberglass, serat terap

Winglet merupakan sayap kecil yang menempel pada bodi sepeda motor berfungsi memberikan gaya tekan ke bawah. Bahan alternatif pada pembuatan winglet sepeda motor dapat dipilih dari spesimen komposit $\mathrm{C}$ yaitu kombinasi fiberglass, serat terap dan fiberglass. Alasan pemilihan karena serat ramah lingkungan, lebih ringan, dan kekuatan yang masih baik untuk material winglet.

Pembuatan winglet menggunakan $100 \%$ fiberglass mempunyai massa lebih ringan dibanding serat kombinasi antara fiberglass dengan serat terap. Bobot winglet pada $100 \%$ fiberglass diperoleh sebesar 106,76 gram, sedangkan kombinasi fiberglass dengan serat terap menghasilkan winglet dengan bobot 210,88 gram.

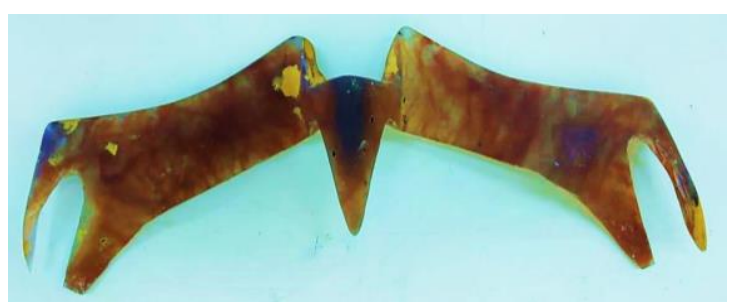

Gambar 10. Winglet dengan spesimen komposit C

\section{Kesimpulan}

Berdasarkan penelitian yang telah dilakukan, kekuatan impak komposit C dengan kombinasi susunan lapisan fiberglass, serat terap, fiberglass sebesar 
2,6581 J/mm² belum mampu mengalahkan kekuatan komposit menggunakan 100\% fiberglass dengan $3,6314 \mathrm{~J} / \mathrm{mm}^{2}$. Kekuatan impak komposit C naik sebesar $79 \%$ dibanding kekuatan impak komposit B menggunakan serat terap murni (100\% serat terap). Kecendrungan void yang besar pada komposit ketika menggunakan serat alam pada metode hand lay up menurunkan hasil kekuatan impak sehingga fiberglass lebih dominan menjadi penentu kenaikan kekuatan impak karena kompaknya serat dengan resin dan penampang serat yang lebih kecil dibandingkan serat terap.

\section{Referensi}

[1]. Rohmawati L, Setyarsih W. Studi Kekuatan Mekanik Komposit Serat Alam/Resin Epoxy. Berk Fis Indones. 2014;6(2):40-6.

[2]. Diharjo K. Pengaruh Perlakuan Alkali terhadap Sifat Tarik Bahan Komposit. J Tek Mesin. 2006;8(1):813.

[3]. Rianto A, Anjiu LD. Kekuatan Mekanik Komposit Berpenguat Serat Kulit Terap Kontinu Sebagai Pengembangan Material Teknik Ramah Lingkungan. Positron. 2018;8(1):21-6.

[4]. Efendi R. Pengembangan Komposit Berbahan Ebonit dengan Kandungan Sulfur 40 PHR yang Diperkuat Serat Bambu untuk Komponen Otomatif. Jurusan Teknik Mesin, Universitas Muhammadiyah Surakarta. 2017.

[5]. Fajri RI, Tarkono, Sugiyanto. Studi Sifat Mekanik Komposit Serat Sansevieria Cylindrica dengan Variasi Fraksi Volume Bermatrik Polyester. J Fema. 2013;1(2):85-93.

[6]. Campbell F. Structural Composite Materials. United States of America: ASM International; 2010. 612 p.

[7]. Pramono A. Komposit sebagai Trend Teknologi Masa Depan, Kajian Teori dan Aplikasi. Fakultas Teknik Metalurgi dan Material, Universitas Sultan Ageng Tirtayasa; 1989.

[8]. Callister WD, Rethwisch DG.
Materials science and engineering: An introduction (2nd edition). Materials \& Design. United States of America: John Wiley \& Sons, Inc.; 2010.

[9]. ASTM Standard D256. Determining the Izod Pendulum Impact Resistance of Plastics. 2010;1-20.

[10]. Nurudin A. Potensi Pengembangan Komposit Berpenguat Serat Kulit Waru (Hibiscus Tiliaceus) Kontinyu Laminat Sebagai Material Pengganti Fiberglass Pada Pembuatan Lambung Kapal. Info Tek. 2011;12(2):1-9.

[11]. Kabir MM, Wang H, Aravinthan T, Cardona F, Lau K-T. Effects of Natural Fibre Surface on Composite Properties. Energy, Environ Sustain. 2011;94-9.

[12]. Aziz SH, Ansell MP. The effect of alkalization and fibre alignment on the mechanical and thermal properties of kenaf and hemp bast fibre composites: Part 1 - polyester resin matrix. Compos Sci Technol. 2004;64(9):1219-30.

[13]. Witono K, Irawan YS, Soenoko R, Suryanto H. Pengaruh Perlakuan Alkali $(\mathrm{NaOH})$ Terhadap Morfologi dan Kekuatan Tarik Serat Mendong. Rekayasa Mesin. 2013;4(3):pp.227234. 